\title{
A Systematic Review of Albiflorous Carnations of North Caucasus
}

\author{
Dudagova A.S. \\ Faculty of Natural Science \\ Chechen State Pedagogical University \\ Grozny, Russia \\ dudagova@mail.ru \\ Shakhgirieva Z.I. \\ Faculty of Biology \\ Chechen State University \\ Grozny, Russia \\ 0892179@mail.ru
}

Baibatirova A.R.

Faculty of Natural Science

Chechen State Pedagogical University

Grozny, Russia

elina-76-76@mail.ru

\author{
Abumuslimova A.A. \\ Department of Biological Research \\ Complex Scientific Research Institute named after \\ H.I. Ibragimov, Russian Academy of Sciences \\ Grozny, Russia \\ burum66@mail.ru
}

\author{
Umaeva A.M. \\ Faculty of Biology \\ Chechen State University \\ Grozny, Russia \\ 0892179@mail.ru
}

\author{
Astamirova M.A-M. \\ Faculty of Natural Science \\ Chechen State Pedagogical University \\ Grozny, Russia \\ astamirova@bk.ru
}

Tasueva E.L.

Faculty of Natural Science

Chechen State Pedagogical University

Grozny, Russia

elizatasu@mail.ru

\author{
Gapaev Ya.S. \\ Department of Biological Research \\ Complex Scientific Research Institute named after \\ H.I. Ibragimov, Russian Academy of Sciences \\ Grozny, Russia \\ burum66@mail.ru
}

\begin{abstract}
The article provides a systematic review of 8 species of the genus Dianthus L. of North Caucasus, focusing on their morphology and ecology. Most of the studied species have a regional ecology and are found in arid basins. But still their potential ecological capabilities are very broad, as evidenced by the results of the semi-desert climate introduction in the Botanical Garden of the Scientific Research Institute, Russian Academy of Sciences in Grozny. While the main limiting factor for expanding these species is apparently their low competitive ability.

There are morphological features that have the most taxonomic meaning for the group of albiflorous carnations: the size of the flower cup and capsula, the lamina shape and segmentation, the shape and size of bract glumes.

All the albiflorous carnations are highly decorative and adaptive to the environment to succeed in the introduction.

All the species under study need protecting, especially stenotopic plants: (Dianthus awaricus, D. jaroslavii, D. eibrusensis) and the species at the boundary of the range (D. arenavirus).

We consider that it is quite necessary to continue studying the species on the boundary of their range as they demand protecting since they are exposed to the least suitable environment. Only direct observations over numerous series of plants in their
\end{abstract}

habitat will allow to obtain and clarify the available data about their range, number and bioecology as well as their potential will help to determine the limits of variability of species. These observations will test the reliability of the feature complex that contributes to differentiating the species.

Keywords - Systematics, morphology, albiflorous carnations, North Caucasus.

\section{INTRODUCTION}

One of the global problems under consideration is the problem of studying and conserving $\neg$ biodiversity. Therefore, the study of species of the genus Dianthus L. in the flora of North Caucasus is of particular interest within comprehensive research and conservation of regional flora. The species of this genus have both economic and decorative meanings. They are rather well studied in the systematic [1-15] aspect. At the same time, the issues of ecology of this genus are insufficiently analysed yet. No relations between anatomical, morphological, ecological and physiological features of adaptive mechanisms of the species have been found. The problem of finding relations between different types of adaptations to the adverse environmental factors in order to 
determine the adaptive capacity of the species of the genus Dianthus of North Caucasus is relevant.

\section{Methods AND Materials}

The material for writing the article is herbariums from different regions of North Caucasus gathered in the period from 2010 to 2018. The expeditionary research where the authors took part covered the territory within the republics of North Caucasus.

The authors gathered more than 200 herbarium samples. In addition, the herbarium collections of the Botanical Institute named after V.L. Komarov RAS (LE), MSU (MW), ISRI RAS, ChSPU, SSU, KBU were reviewed.

The main method of research to analyse taxons is the classical ecological-geographical-morphological method that includes the comparative-morphological approach (study of morphological features and their comparative characteristics) and ecological-geographical approach (identification of environmental relevance and geographical expansion). Most species were observed in their habitat. In the taxonomic studies, we adhered to a moderately polytypical concept of species when recognizing both the existence of large-scale species consistently retaining their characteristics and geographic races that were formed on the basis of adapting to certain environmental conditions.

\section{RESULTS}

The genus Dianthus belongs to the family Caryophyllaceae (Carnations) - one of the largest families Caryophyllales. The family includes about 80 genera and 2,000 species. The extensive genus of Carnation comprising about 300 species is best known in the family and is widely represented in Europe, Asia, Tropical and Southern Africa. Some species are found in North America. Mediterranean region is the centre of the diversity of the species of this genus. A characteristic feature of the genus is having bract pointed or spongy-pointed paleate leaves (epicalyx) arranged in pairs (1-4) at the bottom of the cup and pressed against it as if forming a second outer cup. The following features are also characteristic of the genus Dianthus: a tubular cup that can be cylindrical or oblong with 5 pointed or acuminate and very rarely blunt-end dents with numerous non-anastomosing nervures. Solitary flowers or in cymose inflorescences, sometimes crowded as capitate inflorescences. They are usually androgynous. There are 5 petals with long claws and a horizontally spread pink, purple, whitish or yellowish-green lamina. The lamina is dentate along the upper edge (rarely smooth-edged) or fringed-edged. There are 10 stamens and 2 stiles. The capsule is oblong, sessile or on short carpophore. It is single-numbered and opened at the top with 4 dents; seeds are numerous, usually black, oblate, thyroid and sometimes almost round, elliptical or oblong on the central seed stalk. Monocyclic or permanent grasses, and very rarely shrubs with linear or lanceolate-linear subopposite leaves.

In North Caucasus, the genus Dianthus L. is represented by 23 species (A.I. Galushko, [8].) belonging to almost all sections of the genus. The section Barbulatum is represented by the largest number of species.
The group of albiflorous carnations is represented by 8 species in North Caucasus that are divided in two sections: Leiopetali и Plumaria. Most species belonging to these sections are endemic Caucasian species.

There are difficulties when identifying the species of the group under study that lead to confusion sometimes. Therefore, the key to identify them properly is given below.

A. The key to identify the albiflorous carnation species North Caucasus (A.I. Galushko, [8])

1) There are 6-8 pieces of bract glume near the cup

- There are 4 bract glumes

2) The petals are deeply cut and dentate or fringed

- The petals are crenulated or even smooth

3) The cup is $25-30 \mathrm{~mm}$ long. The petals are deeply cut and dentate Dianthus fragrans - Carnation fragrant

- The cup is $20-30 \mathrm{~mm}$ long. The petals are fringed and dentate D. awaricus - Carnation Avarian

4) The petals are crenulated. The petal lamina is tapered smoothly D. elbrusensis - Carnation Elbrus.

- The petals are pieceless with few dents. The lamina is back triangular and tapered as a claw D. daghestanicus Carnation Dagestan

5) The petals are smooth-edged or dentate

- The petals are deeply fringed and partite. The cup is $22 \mathrm{~mm}$ long $D$. arenarius - Carnation psammophyte

6) The bract glume covers only $1 / 4$ of the cup. The petals from the bottom are brown

- The bract glume is a half of the cup long. $D$. cretaceus

7) The cup is $20-30 \mathrm{~mm}$ long, cylindrical with triangular lanceolar dents D.lanceolatus - Carnation lanceolar.

- The cup is 11-16 mm long, egg-shaped and oblong with triangular dents $D$. jaroslavii - Carnation Oreslava

\section{B. The morphological description of the species}

The section Leiopetali [1], is characterized by the following features: "The lamina of petals is white, yellowishgreenish or pale pink, smooth or dentate at the bottom without hairs."

Within the section there are two types of related species: the series Leptopetali Schischk. and Floribundi Schischk

The series Leptopetali Schischk. - The bract glume is obverse broad egg-shaped and covers $1 / 4-1 / 5$ of the cup; the petals are whity-yellow.

The type of the species: Dianthus leptopetalus Willd. The North Caucasus species D. lanceolatus and D.jaroslavii belong to the type.

Dianthus lanceolatus Stev.,[2]; Boiss.,[1]; Grossgame [7]; Shiskin,[5]; Galushko,[8]

There is a single stem or there are several stems, $40-70 \mathrm{~cm}$ high, straight or curved sometimes, knotty, simple or branched at the top, grey and bare or pubescent at the bottom. Lower leaves are linear, up to $11 \mathrm{~cm}$ long, longer than their internodes, 2-3 mm wide with 5-7 nervures, lacerate along the 
edge, 2-7 $\mathrm{mm}$ long, screwed into the axil at the bottom, middle and upper stem leaves are much shorter. Flowers have long stalks, single at the end of stems and branches; the cup is 20 30 (33) $\mathrm{mm}$ long and $4-6 \mathrm{~mm}$. wide; bracts are leathery, whitish, immediately drawn into a green pointed acumination (1-4 mm long). They are adjacent to the cup and cover it up to $1 / 4-1 / 5$, petals are $1 / 1 / 2$ times longer than the cup. They are whitish-yellowish, greenish on the underside. The lamina is oblong, 7-15 mm long and 7-8 $\mathrm{mm}$ wide. It is unevenly crenulated at the top. The capsule is equal or longer than the cup.

It grows on grassy slopes, in steppes, including sandy ones. It can be found anywhere from lowlands to the lower mountain zone.

It grows in all regions of Ciscaucasia (Fig. I).

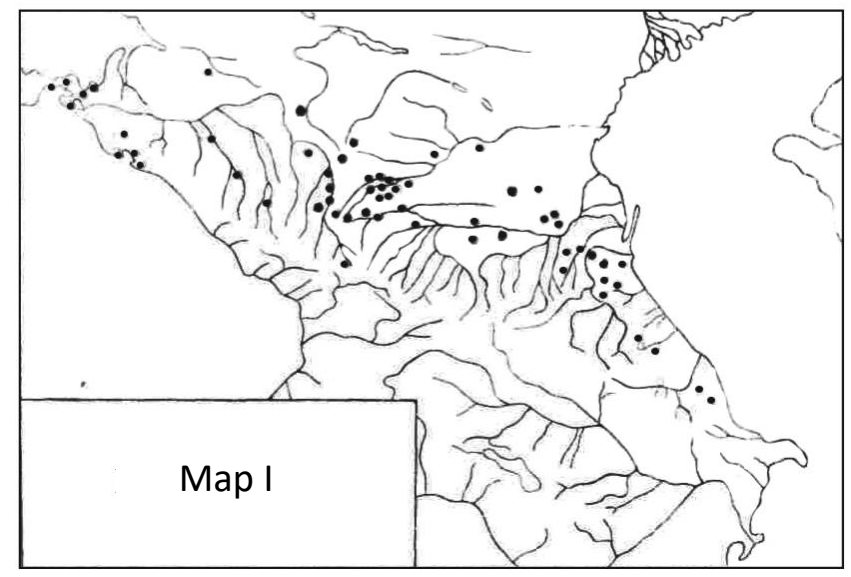

- Dianthus lanceolatus Stev.

Fig. 1. Map of the plants habitats (Dianthus lanceolatus)

General expansion: European part (Black., Middle Dnieper., Zolzh.-Don., Lower-Don.), Lower. Volzh. (SouthWestern); Western Zakavk. (Novorossiysk, Gelendzhik).

The type: South Podolia.

Specimens studied (specimina examinata): - The lake Kissyk, $35 \mathrm{~km}$ north of the station Chervlennaya 29.07.64 A.I. Galushko; Gelendzhik, the slopes of the Margel Ridge to the north) from the city 21.98.71 A.I. Galushko; in the region of the mountain pass from Makhachkala to Buynaksk 5.05.90 A.I. Galushko; Pyatigorsk region, Mt. Lysaya 11.07.91 A.I. Galushko, M.A.Taysumov.

Note. The study of the plants from different points of the range shows that the variability within the species is low and it affects the degree of branching, the size of the leaves, the cup, the lamina and the colour of the petal.

The plants from Gelendzhik surroundings have the least branched stem. It is branched only in the upper part. The plants from Dagestan are very different from other plants. They have the shortest but the most branched stem. The pubescence of the lower part of the stem is characteristic of samples from Gelendzhik and from the city of Lysa (Pyatigorye). B.K. Shishkin in the [5] consider all these plants with a pubescent stem as an example of $D$. lanceolatus $f$. pubescens. The size of the cups varies in different populations as follows: from 25 to $27 \mathrm{~mm}$ (Gelendzhik), 22-30 (32) (the mounting pass to Buynaksk). But no geographical dependence of this feature is observed.

The amplitude of the variability of the length and width of the leaves is as follows: 4 to $6 \mathrm{~cm}$ long and $2 \mathrm{~mm}$ wide (the mounting pass to Buynaksk); $6-11 \mathrm{~cm}$ and $1.5 \mathrm{~mm}$ (Mt. Bald); $3-5 \mathrm{~cm}$ (Gelendzhik); 2-6 cm and 2-2.5 mm (Kissyk). Thus, the connection with the highland and humidity of the territory can be observed.

According to the information above, we believe that it makes sense to make some changes in the description of the species in the "Flora of the USSR". B.K. Shishkin in the description of the species indicates features that do not correspond to the studied samples: the stem height is $40-60$ $\mathrm{cm}$; lower leaves are up to $7 \mathrm{~cm}$ long; cups are $17-22 \mathrm{~mm}$ long; petals are whitish-yellow or pink; the petal lamina is 10$15 \mathrm{~mm}$ long and 4-6mm wide. Other characteristic features of the species that are not listed in the description: the capsule is equal to or longer than the cup; petals are greenish on the underside. One more characteristic feature of this species that differs it from the others should be mentioned: the petals of the plants are closed in the daytime.

Dianthus jaroslavii Galushko, Galushko [9. 8].

It has few stems. They are erect, $20-40 \mathrm{~cm}$ high, bare or floccose at the bottom, branchy at the top. The branches are obliquely growing backwards. The leaves narrow and linear, 4-7 cm long, 0.7-1.5 (2) $\mathrm{mm}$ wide, pointed. The stem leaves are usually bare, 3 (5), they are unequal being screwed into the axil at the bottom, 3-4 mm long. Flowers are solitary at the top of the stem having a few branches. The cup is ovate-oblong, 11-16 (18) $\mathrm{mm}$ long, 4-5 $\mathrm{mm}$ wide, bear with wide-triangular dents, bracts have 4 leathery, round-obovate glumes. They are short pointed, being $1 / 3$ the length of the cup at the top. The petals are white, their lamina is ovate, $5 \mathrm{~mm}$ long, $2.5-3 \mathrm{~mm}$ wide. The capsule is slightly longer than the cup.

It is found only in the Paleo-Elbrus region (arid slopes in Baksan and Chegem), in the Middle Zone at the altitude of 1100 - 1630 m. Endem. (Fig. 2).

The type: Hegem, surroundings of Upper Chegem, A.I. Galushko, M.A.Taysumov. (LE). The studied specimens: Kabardino-Balkaria, rav. R. Zhylgy $2-5 \mathrm{~km}$ from Upper Chegem, 1.08.72 A.I. Galushko; surroundings of Top. Chegem, the left bank of the Zhylgy-Su on grassy slopes after the ancient stairway, 26.05.90 A.I. Galushko, M.A.Taysumov.

Note: The study of herbarium specimens and plants from the Botanical Garden of the ChGU (1988-1990) transported from locus ciassicus shows that the variability within the species is very low. There can be found plants with 2 and 6 bracts glumes with a smoothly edged lamina of the petals. The length of the cup in some plants is bigger than the first given description and reaches $22 \mathrm{~mm}$ in length. 


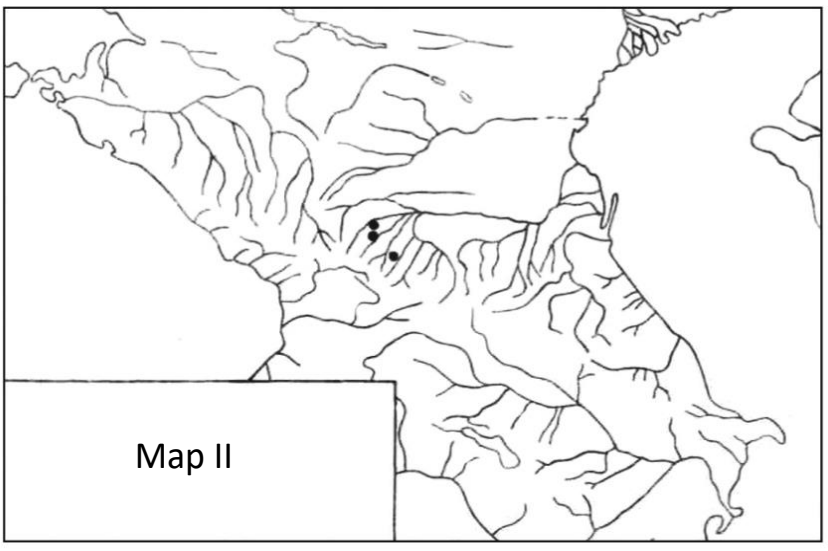

- Dianthus jaroslavii Galushko

Fig. 2. Map of the plants habitats (Dianthus jaroslavii)

The lower side of the lamina of the plants in the Botanical garden is greenish-purple (the fact that requires further study).

A. I. Galushko finds this species to be similar to the Transcaucasian species:

D. inamoenus Schischk. and especially the azkurensis Sosn. that are referred to the series Leiopetali. However, the relation to D. lanceolatus is clearly seen. But the position of the petals of $\mathrm{D}$. jroslavii in the daytime is somewhat different than

D. lanceolatus. Floribundi Schischk. - Bracts are ovoid or ovate-lanceolate and cover $1 / 3-1 / 2$ of the cups, or reach the dents of the cup; petals are pink or white.

Most studied species belong to this series: D. fragrans, $D$. cretaceus, D. daghestanicus, D. ebrusensis.

Dianthus fragrans Adams [10]; Galushko, [8]

The plant is with a branched caudex; stems are few, they are straight or geniculate, simple or subramose at the top, having from 1 to 5 flowers, $30-60 \mathrm{~cm}$ high. Leaves of the barren shoots are short; stem leaves are shorter than the internodes, they are linear-subulate $3-10 \mathrm{~cm}$ long, up to 1.5 $\mathrm{mm}$ wide, pointed, rough at the edges, screwed into the axil up to $3 \mathrm{~mm}$ long at the bottom. The tubular cup is $25-35 \mathrm{~mm}$ long with pointed, edge membranous dents reaching $1 / 3$ of the cup. There are 6-8 bract glumes that are leathery, oblong-obovate or elongated-elliptic, they are narrowed or obtuse to the top with a short or longer acumination that sometimes exceeds the glumes, reaching the middle of the cup. The lamina of petals is $8-12 \mathrm{~mm}$ long, $9-10 \mathrm{~mm}$ wide. It is white, obovate, up to $1 / 3$ with an incised edge.

It grows on stony, gravelly, clay, grassy slopes, on calcareous rocks, in meadows, among bushes from the lower to the middle mountain zone.

In North Caucasus it is widespread in all mountainous areas (Fig. 3).

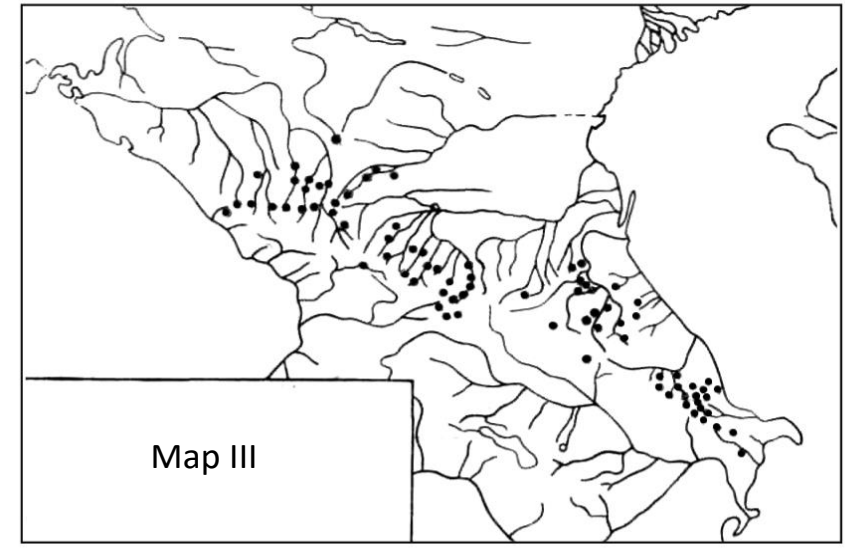

- Dianthus fragrans Adams

Fig. 3. Map of the plants habitats (Dianthus fragrans)

General expansion: Caucasus (the Greater Caucasus, mainly on the northern slope of Dagestan, Eastern Transcaucasia). Ajikend). Endem of Caucasus.

The description from the area of Pyatigorsk (the fortress Konstantinogorskaya).

The studied specimens: Dagestan, rav. of the Gyulgerichay, surroundings of the settlement Khiv. M.A. Taysumov VIII.89; surroundings of the Kezenoy-Am, slopes of the Andean ridge.

Note: The study of herbarium samples and plants in the Botanical garden contributed to understanding that the number of bracts, their size and especially the size of the dents of the lamina are susceptible to changes.

In some plants the lamina is fringed. The dents of the lamina of some plants are the same in length, while they are different for other plants. The petal lamina of plants from Dagestan has a greenish spot at the bottom (the fact requires further study). The plants from the surroundings of Lake Kezenoy-Am have 4 light purple bract glumes.

D. cretaceus Adams, [11]; Biossier [1]; Shishkin, [5]; Galushko [8].

The stems are numerous, erect or geniculate, bare, simple or slightly branched, $20-40 \mathrm{~cm}$ high. The leaves are narrowlinear or linear-lanceolate, pointed, 3-7 mm long and 1-2 mm wide, rough at the edge, at the bottom they are screwed into the axil $2-4 \mathrm{~mm}$ long. The flowers on the top of the stem and branches are solitary. The cylindrical cup is $20-30(35) \mathrm{cm}$ long, and 3-4 mm wide with sharp dents reaching $1 / 3$ of the cup. There are 4 bract glumes that are obovate-oblong or elliptic. They are immediately drawn into a long, often green acumination reaching the dents of the cup or exceeding them. Often the cup as well as the bracts are purple. The petal lamina is $6-10 \mathrm{~mm}$ long and $5-10 \mathrm{~mm}$ wide. It is obovate and white on both sides or pinkish underneath. It is sinuate on the edge or nearly smooth. 
It grows on rocky and grassy slopes and on azides in the subalpine and alpine zone up to $3000 \mathrm{~m}$.

The expansion in North Caucasus: Verkhne-Labinskiy, Chalmyk-Kuban areas (in the west) to Dagestan (in the east) Fig. 4.

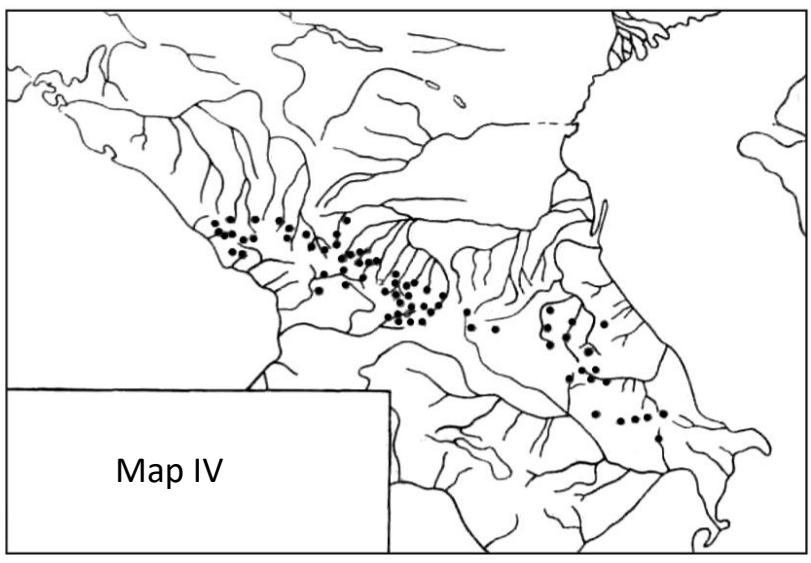

- Dianthus cretaceus Adams

Fig. 4. Map of the plants habitats (Dianthus cretaceus)

General expansion: Big Caucasus, Eastern and Western Transcaucasia, Talysh, Asia Minor, Arm-Kurd.

The studied specimens: the left side of Cherek Balkar 15 $\mathrm{km}$ from Mukhal to Shtul 11.07.63. A. I. Galushko; Armenia, southern slope of Alagez, $2500 \mathrm{~m}$ 17.8.63. A. I. Galushko; the shore of the lake Sevan.3.63. A. I. Galushko; the upper course of the Fortanga, the left side of the gorge, on the limestone rocks (surroundings of the settlement Khay. C. high), $1600 \mathrm{~m}$. 16.8.70 Prima V. M., Umarov M. U.; the gorge of the Armkhi, the rocky slope. 3.7.71. Zermich; the gorge of the Hyzny-Su in the region of the Rocky Ridge 1.7.72. A. I. Galushko; Fisht, the slope of Belorechenskiy mountaining pass 16.8.72. A. I. Galushko; Genaldon, the way to the glacier 25.8.72. A. I. Galushko; Nazran region, the right side of the gorge of the Muzich (the left tributary of the Assy), the meadow, 10.7.88; North Ossetia, the left side of the Ardon, opposite to Buron. 19.6.89. M.A. Taisumov.; Kabardino-Balkaria, Kzny-su, 3 km from the Rocky Ridge, crystalline rocks on the grassy slopes, 1600 m, 27.0590 Galushko, M. A. Taisumov; KabardinoBalkaria, the gorge of the Baksan, surroundings of the settlement Bylym. 10.07.91. A. I. Galushko, M. A. Taisumov.

Note. The species has complex synonymics. It has been repeatedly described under different names and in different taxonomic ranks by many authors who did not care enough to identify the true origin of the species. The fact caused a considerable nomenclature confusion. As it was already mentioned in the other chapter, the first description of $D$. cretaceus was made by Adams in [10]. Grossheim (1.c.) and Galushko (I. c.) use the name. Shishkin [5] finds this species similar to D. petraeus, described by M. Bieberstein in [11], but puts their identity in question. Schmalhausen (1.c.) considers it in the group of the species D. fragrans - fragrans D. D. petraeus.
As shown in the above synonymics, there have been made repeated attempts to point out specific types on the base of the vast range of this species. Especially often it was confused with similar D. multicaulis Boiss et Huet. in the surroundings of Erzerum.

The species is very polymorphic. The study of herbarium samples from various points of the range and plants in the former Botanical garden of $\mathrm{ChGU}$ shows that the variability within the species affects the size, the degree of serration of the lamina, the height of the stems, the size of the leaves, cups, the number of bracts.

The size of the cup of plants from different points of the range varies as follows: $20-23 \mathrm{~mm}$ (Alagez), 23-27 (Armkhi), 23-28 (Buron), 25-27 (Baksan), 28-30 (Cherek, Genaldon, Muzhich, Hyzny-Su), 30-32 (Fisht), 30-35 (Fortang). Shishkin in "Flora of the USSR" and Grossheim in the "Flora of Caucasus" claim $20 \mathrm{~mm}$ length of the cup approximately, but as shown above the cup is much larger.

The amplitude of variability of the size of the petal lamina in different populations is the following: 5-6 $\mathrm{mm}$ long and 5 mm wide (Hyzny-Su), 7-8 and 7 (Baksan) with the largest leaf dents (1-2 mm long), 10-12 and 10-12 (Fortang), 8-10 and 5-6 (Alagez), 7- 8 and 5-6 (Buron).

Measuring the height of the stems showed that highland and arid plants (Alagez, Baksan) are the most undersized.

Plants from Baksan, Fortang and Armkhi often have 6 bracts.

Plants from Fortanga have a smooth petal lamina.

D. daghestanica Kharadze [12]; Galushko, [8].

It is perennial and lignescent at the bottom. It has numerous upgoing bare, simple or branched at the top stems of $17-50 \mathrm{~cm}$. Leaves are linear, pointed, bare and rough at the edge. They are $25-55 \mathrm{~mm}$ long and 1-2 $\mathrm{mm}$ wide, screwed into the axil- 2-3 mm long. Flowers are solitary or there are 23 at the top of branches. The cup is 20-25 mm long, 3-4 mm wide. Sometimes it is deeper than $1 / 3$; it is incised into linear, pointed, pubescent dents; it is green at the bottom of the dents and tapered at the top. There are 6-8 bract glumes that are membranous, obovate with a tapered short acumination up to the half of the cup. The petals are white with a spatula or slightly dentate lamina that is tapered into a claw, up to $5 \mathrm{~mm}$ long and $4 \mathrm{~mm}$ wide.

It grows on dry slopes in the middle zone, often it is a part of phryganoid vegetation.

The expansion in North Caucasus: to the East of the Terek, especially in the Verkhne- Sunzhensky, Chechensky (in the east) districts, Central Elbrus and Andi-Samursky districts (Fig.. 5). 


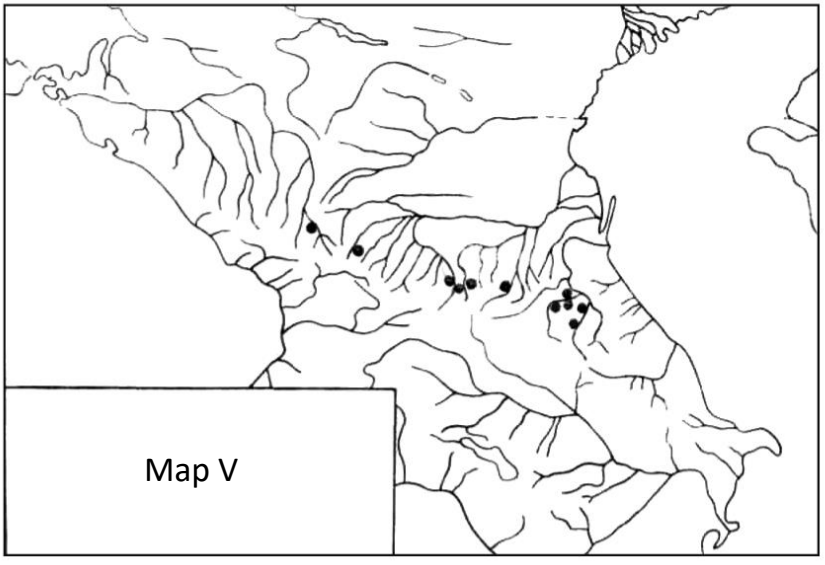

- Dianthus daghestanicus Charadze

Fig. 5. Map of the plants habitats (Dianthus daghastanicus)

The studied specimens: Targim Basin VII.88 A. Galushko; the ravine of the Kerig (the right tributary of the ChantyArgun river), the right side VIII.89. A. I. Galushko.

Note. Before the works by Kharadze, this species was confused with $D$. fragrans herbarium. Kharadze writes that "from the first $D$. daghestanicus it differs in a narrower and shorter cup that is usually (28) 30-35 mm long for D. fragrans, while its cup is tapered at the bottom of the dents, especially by the end of flowering. D. daghestanicus has a solid or slightly dentate on the top petal lamina, while $D$. fragrans usually is characterised by a more or less deeply incised lamina.

Further, Kharadze points out that, first, it is a slightly longer and narrower cup what differs it from the polymorphous species $D$. cretaceus, which cup is approximately $15-20 \mathrm{~mm}$ long. Second, it has 6-8 bract glumes that are usually shorter, and it has a shorter, not grasslike acumination. But the analysis shows that the size of the cups of these types is almost the same.

A. Kharadze also correctly points out the differences in the ecology and geographic expansion of these species. She says that D.daghestanicus (except Dagestan) is also characteristic of the longitudinal valleys of the northern slope of the eastern and partially central part of the Main Caucasus Ringe, while D.fragrans grows only in the western part of the northern slope of the Main Ridge. D.cretaceus grows in the highland region of Caucasus, and is a part of meadow aggregation of the Subalpine and Lower Alpine Zones.

The study of herbarium materials and plants from Targim showed that the length of the biggest cup is $30 \mathrm{~mm}$ long. The petal lamina is also much larger: 7-9 $\mathrm{mm}$ long and 5-6 mm wide.

Plants with 4 bract glumes are occasionally found.

The cup is light purple sometimes.
Plants from Kerigo have a smooth-edged petal lamina, while plants from Targim basin have a similar petal lamina to $D$. cretaceus. The other features are characteristic of $D$. daghestanicus.

The type: Dagestan, Charodinsky district, between the settlements Tsurib and Gidib, $1500 \mathrm{~m}$, phryganoid vegetation. 26.VIII.49. M. Sakhokia; 26. VIII.49. A. Kharadze, L. Khintibidze. (TBI).

\section{D. elbrusensis Kharadze, Kharadze [12]; Galushko, [8].}

It is perennial and lignescent at the bottom. It has numerous upgoing practically bare at the bottom, pilose at the top stems that are simple or slightly branched,17-50 cm high. Leaves are linear, pointed, rough on the edge with short hairs, $22-35 \mathrm{~mm}$ long, $1.5 \mathrm{~mm}$ wide, at the bottom screwed into the axil of $1.5-3 \mathrm{~mm}$ long. The flowers are solitary at the ends of the stems and elongated few 1-4 branches. The cup is 18-25 $\mathrm{mm}$ long and $3-4 \mathrm{~mm}$ wide. It is incised up to $1 / 3$ or more into pointed, lanceolate, pubescent parts. The cup is greenish with purple spots. There are 6-8 bract glumes that are membranous, with purple spots. Usually they are $1 / 3$ or a half of the length of the cup and obverse broad egg-shaped, they are smoothly tapered into a short acumination. The petals are whitish with the spatulate, dentate on the edge, lamina. They are $5 \mathrm{~mm}$ long and $4 \mathrm{~mm}$ wide, smoothly tapered in the shape of a claw.

It grows in the Subalpine and Lower Alpine zones, rarely in the Mid-mountain zone. It is found on dry slopes and in rocky places, often it enters the composition of mountainsteppe and steppe meadow vegetation.

The expansion in North Caucasus: Central Elbrus, ElbrusDagestan regions. Endem (Fig. 6).

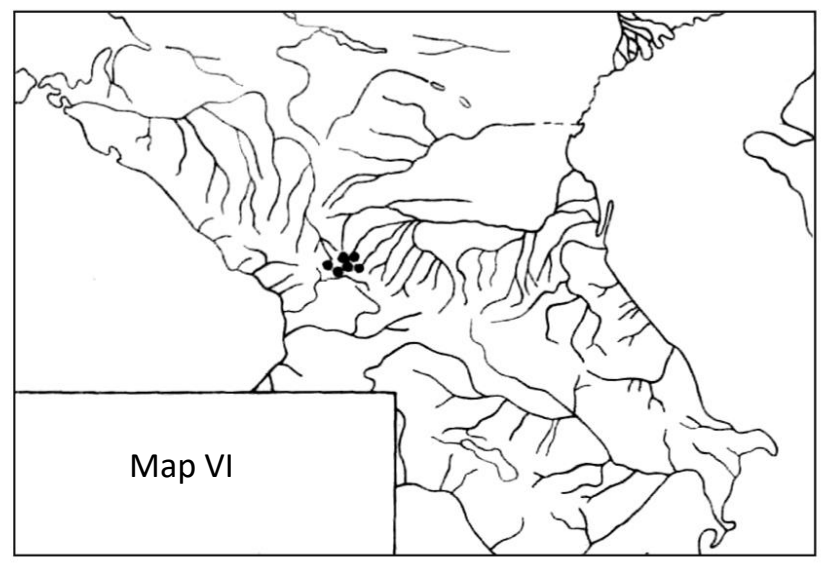

- Dianthus elbrusensis Charadze

Fig. 6. Map of the plants habitats (Dianthus elbrusensis)

The type: Balkaria. Upper reaches of the Baksan. The left side of the Irik 17. US.56. Gagnidze, I. Lachashvili. (TRI)

Note: A. Kharadze says that the size of flowers makes this species similar to $D$. daghestanicus but the species features in the dendate petal lamina tapered to the bottom, whereas 
D. daghestanicushas petals smooth on the edge or with distant dents tapered steeply in the shape of a claw. For $D$. elbrusensis in contrast to D.daghestanicus it is characteristic to have shorter acuminations of bract glumes and pubescent stems in the upper part.

A.I. Galushko [9] writes that D. elbrusensis is similar to $D$. cretaceus and $D$. fragrans, but it is referred to the type Leptopetali of the section Leiopetali. We share A.Kharadze's opinion that according to the shape of the petals D.elbrusensis is more similar to the species $D$. fragrans and can be considered as belonging to the same series Floribundi Schschk of the section Leiopetali. But D.elbrusensis differs in some features. The smaller size of flowers as well as bract glumes are the most essential among them. D. elbrusensis has a cup of 18-25 mm long and bract glumes tapered into short acuminations that are $1 / 3$ or $1 / 2$ of the length of the cup. $D$. fragrans has a cup of $28-35 \mathrm{~mm}$ long and its bract glumes are up to the dents of the cup.

A. Kharadze also claims that there are some differences in geographic expansion and ecology of D. elbrusensis and related to it $D$. daghestanicus and $D$. fragrans. The areal of $D$. elbrusensis is isolated from the habitat of D. daghestaniarus. D. elbrusensis substitutes D. daghestaniarus in the western part of Central Caucasus. The D. fragrans species is characteristic of the piedmont of Greater Caucasus, and $D$. elbrusensis grows from the Middle to the Upper Mountain Zones. Its area covers Elbrus region (in the west from the Upper Kuban River to the east slopes of Elbrus and to the upper reaches of the highlands of central parts of Greater Caucasus).

Unfortunately, the author failed to see this species in the herbarium or in nature.

The section Plumaria ('opiz) Asch et Graebn. Sypons, 1921, 5: 2: 408; Fimbriati Boiss., 1867, Fi.Orient., I : 480.

It is perennial. The petal lamina is bare or with short hairs, fringed up to $1 / 2$ or deeper, very rarely to $1 / 4$ with linear parts; perennials.

The series Arenarii Schischk. The petals are white, pinkish, the solid lamina is rather large and almost elliptical.

Dianthus arenarius L., Linneus, [15]; Shmalgausen, [14]; Grossheim, [7]; Shishkin, [5]; Galushko, [8].

It forms rather dense turf with leucocarpous, leafy, short soboles. Flower-bearing stems are straight, 10-30 cm high. The stems can appear simple or sometimes branchy at the top; they can be bare, somewhat blue-grey or green. Leaves of the leucocarpous shoots are linear or lanceolate-linear, $1.5-3.5 \mathrm{~cm}$ long and 1-2 mm wide, straight or sickle-shaped, rough on the bottom surface. Leaves on the stem are smaller (up to $2 \mathrm{~cm}$ long) and screwed into the axil at the bottom, 1-2 mm long. The flowers are fragrant, solitary or in a tiny number; the cup is cylindrical, 18-20 (23) $\mathrm{mm}$ long with pointed dents; 4 bract glumes are ovate with short acumination and cover $1 / 4$ of the cup; the petals are white, pink sometimes, and the lamina is heavily fringed; it is divided into linear fibriform parts, on the upper side it is pubescent with a greenish spot and purple blotches.
The habitat is sandy places, meadows, sandy pine forests.

The expansion in North Caucasus: Central Pre-Caucasian region (marked by Guldenstedt for Terek) (Fig. 7).

General expansion: The European part of the USSR (KarlLapl., Verkh.-Dnieper., Middle-Dnepr., Verh.-Volzh., Volzh.Kam., Volga., Scandinavia, Central Europe).

The description from sands of Europe. The type in London.

Ciscaucaaicae Char Series., 1950, New Caucasian carnations. Notes on systematics and geography of vegetation Tbilisi, Bot. garden, vol. 16.

Diahthus awaricus Kharadze, Kharadze [12]; Galushko, [8].

It is perennial and lignescent at the bottom. It has numerous upgoing bare, simple or branched at the top stems of $17-50 \mathrm{~cm}$. The leaves are linear, pointed, bare, 2-2.5 $\mathrm{mm}$ wide, $5-7 \mathrm{~mm}$ long; at the bottom they are screwed into the axil up to $2 \mathrm{~mm}$ long. The flowers are solitary or there are $2-4$ ones at the top of the stems and at the ends of obliquely upwarddirected geniculate branches. The cup is $25-30 \mathrm{~mm}$ long, 4-5 $\mathrm{mm}$ wide, elongated cylindrical, almost $1 / 3$ incised into narrowl lanceolate pointed dents, greenish, sometimes with purple stripes. 6-8 (10) bract glumes are oblong-elliptic, membranous along the edge, tapered to the top and gradually turned into acuminations. They usually cover a half of the cup up to its dents. The upper couple of membranous is close to the flower. The petals are white or pink. The petal lamina is oblong (approximately $12 \mathrm{~mm}$ long), bare, tapered into the shape of a claw. It is clearly seen over the cup; and incised into narrow-lanceolate parts with the lamina that is not incised. It is up to $4 \mathrm{~mm}$ wide.

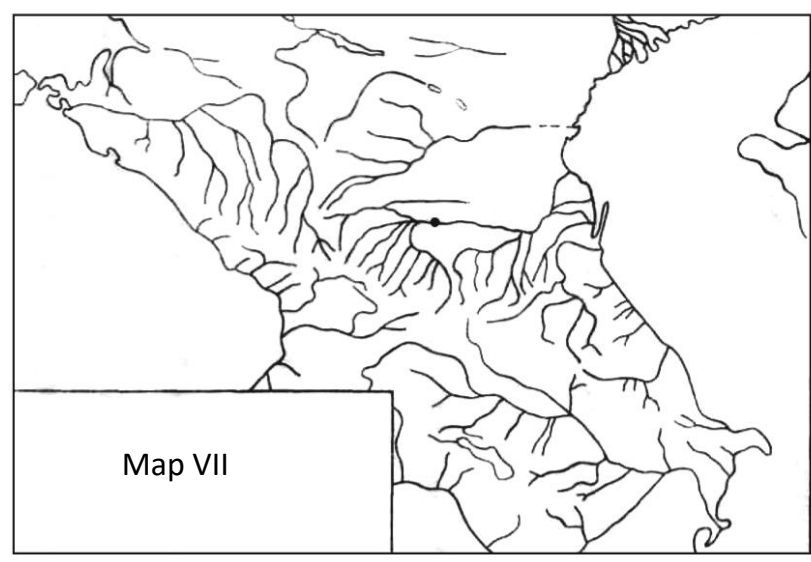

- Dianthus arenarius L.

Fig. 7. Map of the plants habitats (Dianthus arenarius) 


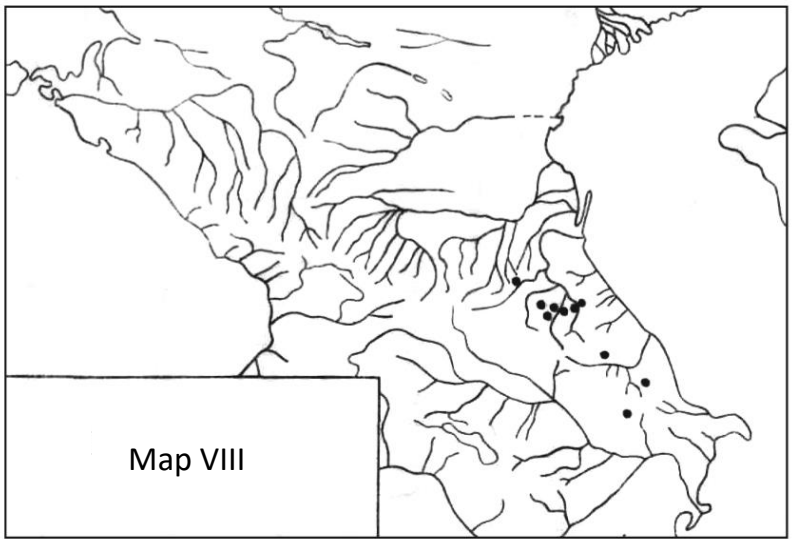

- Diahthus awaricus Charadze

Fig. 8. Map of the plants habitats (Dianthus awaricus)

It grows on dry slopes in the Middle Zone.

The expansion in North Caucasus: Central Dagestan, Andian-Samur, Caspian regions. Endem. (Fig. 8).

The type: Dagestan. Near the Upper Gunib. 22.VIII.49. A. Kharaze, and L. Khintibidze (TBI).

The studied specimens: Dagestan, the gorge of the Kurakhchay, surroundings of the settlement Kurah, US.89. M.A. Taisumov.

Note: Before the work by A. Kharadze, the species was considered similar to D. fragrans and they were confused in the herbarium. A. Kharadze claims that $D$. waricus is different from $D$. fragrans through their oblong but not spatulate shape of the petal lamina as well as through their bract glumes smoothly tapered into the acumination. Moreover, D. waricus has relatively smaller flowers. We share A.Kharadze's opinion She refers this species to the section Piumaria as it has an oblong petal lamina, whereas Leiopetali has a spatulate or obovate petal lamina. We also agree that this species cannot be referred to any of the known series of this section as Criniti has a petal lamina that is not so deeply incised. The fact allows to add it to the species of the series Arenarii Schischk but only to some extent because it has longer bract glumes and, therefore, it is more correct to put this species in a special series - Ciscaucasicae Charadze.

The study of herbarium specimens and plants shows that the variability of $D$. awaricus is low and affects such features as the height and branching of the stem, the size of the lamina as well as the number and size of the bract glumes. After introducing the plants to the city of Grozny, their stems become higher and branchy, whereas the other features remain unchangeable.

\section{D. tichomirovii Deviatov, Taisumov et Teimurov [13].}

It is perennial with a branched caudex; It has numerous upgoing, bare, simple or branchy in the upper part stems, 35$60 \mathrm{~cm}$ high. The leaves are linear-subulate, pointed, soft, rough at the edges and screwed into the axil $3-4 \mathrm{~cm}$ long. The upper leaves are membranous, 1-2 $\mathrm{cm}$ long, 1-3 cm away from the flower. The flowers are large, $2.5 \mathrm{~cm}$ in the diameter, solitary at the ends of the stems and few branches. The cup is cylindrical, greenish, 30-35 $\mathrm{mm}$ long, 3-3. $5 \mathrm{~mm}$ wide, with pointed and ciliate dents that cover $1 / 3$ of the cup. 6-8 eggshaped whitish leathery bract glumes are narrow membranous at the edge, with a short acumination; they cover $1 / 3$ of the cup. The petals are white with an olive-green spot that occupies $1 / 4$ of the lamina at the bottom; they are pink along the nervures on the bottom side; after flowering they are entirely pinkish, the lamina is broadly obovate or obovatespatulate, up to $12 \mathrm{~mm}$ long and $9-10 \mathrm{~mm}$ wide; it is deeply $(1 / 3)$ incised at the top; $9-10$ dents are linear, pointed; the claw is 30 (33) $\mathrm{mm}$ long; in the lower parts $(2 / 3)$ it is olive-green. It blooms in July.

It grows on rocky slopes and in rocky places in the Middle Zone. Heliophyte.

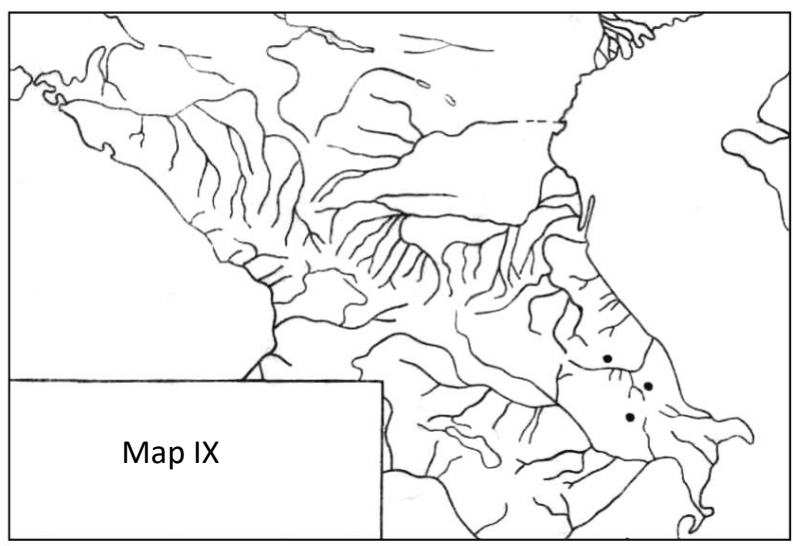

- Dianthus tichomirovii Deviatov, Taisumov et Teimurov.

Fig. 9. Map of the plants habitats (Dianthus tichomirovii)

The type: Dagestan, the gorge of the Kurakh, in the surroundings of the settlement Kurakh, in rocky places in the Middle Zone.VIII. 1989, M. Taisumov. (map 9.).

Relationship. It is close to D. fragrans Adams, which is clearlyl distinguished with olive-green spots at the bottom of the petals; after flowering it becomes pinkish (at the beginning of blooming it is pinkish along the nervures only). D. fragrans has white petals without spots, after flowering it is not pinkish.

\section{CONCLUSION}

Thus, albiflorous carnations in the North Caucasus are represented by 8 species and most of them are located in Central and Eastern Caucasus.

Most of the studied species have a regional ecology and are found in arid basins. But still their potential ecological capabilities are very broad, as evidenced by the results of the semi-desert climate introduction in the Botanical Garden of the Scientific Research Institute, Russian Academy of Sciences in Grozny. While the main limiting factor for expanding these species is apparently their low competitive ability. 
There are morphological features that have the most taxonomic meaning for the group of albiflorous carnations: the size of the flower cup and capsula, the lamina shape and segmentation, the shape and size of bract glumes.

All the albiflorous carnations are highly decorative and adaptive to the environment to succeed in the introduction.

All the species under study need protecting, especially stenotopic plants: (D. awaricus, D. jaroslavii, D. eibrusensis) and the species at the boundary of the range (D. arenarius)

It is possible that currently known species of albiflorous carnations in North Caucasus are still not complete, and new species will be discovered. A lot of areas have not been explored yet. It is recommended that inner Dagestan should be explored in arid basins and in small gorges, as the study of $D$. jaroslavii showed that the species can have a restricted area in a gorge.

Moreover, that is Trans-Caucasian region where albiflorous plants should be studied in more detail. It will contribute to recognizing similarities and differences as well as relations between the species in North Caucasus and TransCaucasian Region Nowadays these issues have not been brought to light.

Special attention should be paid to the species with the regional locality as having distinguishing features $(D$. cretaceus from Targim Basin and D. cretaceus from Pyatigorsk Region (Beshtau) referred to as polster plants. The analysis of the species would also provide insight into the relation of taxons within the group. D. lanceolatus having specific characteristics should be focused on too.

It is recommended that we should continue finding out the most resilient and xeromorphous species that will succeed in the introduction.

Keeping on studying the species growing at the boundary of their range is essential since they are exposed to the least suitable environment. Only direct observations over numerous series of plants in their habitat will allow to obtain and clarify the available data about their range, number and bioecology as well as their potential will help to determine the limits of variability of species. These observations will test the reliability of the feature complex that contributes to differentiating the species.

\section{References}

[1] Biossier Flora orientalis, vol. 1, Paris, 1867. p. 1296.

[2] Ch.Steven, "Catalogue des plantes rares ou nowelles, observees pendant un voyage autour du Caucase orientale", Mem. Soc. Nat. Moscou, vol. 3 , 1812, pp. 244-270.

[3] C.F. Ledebour Flora rossica in, vol. ,. Stuttgart, 1842, p. 267.

[4] B. K. Shishkin, "Caryophyllaceae -caryophyllaceous", In book Flora of Central Russia, P.F. Mayevsky Ed. Mocow; Leningrad, 1933, pp. $306-$ 330 .

[5] В. K. Shishkin, “Раздел ГВОЗДИЧНЫЕ”, In book Flora of the USSR, vol. 8,1936 , pp. 37-40.

[6] E. V. Schiffers, Vegetation of North Caucasus and its natural forage lands, Moscow: AS USSR, 1953, pp. 37-40.

[7] A. A. Grossheim, Analysis of the flora of Caucasus, Bot. inst. Az. phil. USSR Academy of Sciences: Baku, 1936, p.260.

[8] A. I. Galushko, Flora of North Caucasus. Determinant, Publishing house of Rostov University, vol. 1, 1978, p. 318.

[9] A.I. Galushko, "Novel taxons", Bulletin of higher plants systematics, vol. 6, 1969, pp. 209-222.

[10] M. Adanson Familles des Plantes in 2 p. P. 2. Paris, 1763. 640 p.

[11] F.A. Bieberstein (Marschall), "Flora taurico-caucasica, exhibens stirpes phanerogamas in Chersoneso taurica et regionibus", In Caucasicis sponte crescents, vol. 1, Charkov, 1808, p. 429.

[12] A.L. Kharadze, "New caucasicis carnations", In Notes on systematic and geography of Tbylisy botanical garden, vol. 16, 1951.

[13] A.G. Deviatov, M.A. Taysumov, A.A. Teymurov, "New species of the genus Dianthus L. (Caryophyllaceae) from Dagestan”, Bulletin. of the Moscow Society of the Testers of Nature, vol. 104, no. 2, pp. 37-40

[14] Schmalhausen J. 1892. Neue Pflanzenarten aus dem Kaurasus berichte der Deutsch. Botan. Gesellsch. 10 